\title{
Diversity of Spiders in Three Habitat Types in Impasug-Ong Protected Area, Bukidnon, Philippines
}

\author{
Geonyzl Lepiten Alviola ${ }^{1,2}$, Abdel Muamar Alonto Disomimba ${ }^{3}$ \\ ${ }^{1}$ Biology Department, Davao Doctors College Gen. Malvar St., Davao City, Philippines \\ ${ }^{2}$ Biology Department, Central Mindanao University Musuan, Maramag, Bukidnon, Philippines \\ ${ }^{3}$ Saber St., Marawi City, Lanao Del Sur, Philippines
}

\section{Email address:}

Geonyzlalviola27@gmail.com (G. L. Alviola), abdel_mimi@yahoo.com (A. M. A. Disomimba)

\section{To cite this article:}

Geonyzl Lepiten Alviola, Abdel Muamar Alonto Disomimba. Diversity of Spiders in Three Habitat Types in Impasug-Ong Protected Area, Bukidnon, Philippines. Ecology and Evolutionary Biology. Vol. 2, No. 6, 2017, pp. x-x. doi: 10.11648/j.eeb.20170206.12

Received: August 10, 2017; Accepted: September 6, 2017; Published: December 27, 2017

\begin{abstract}
Araneae are widely distributed in all types of environment. The group usually served as pest controllers in most agrosystem habitat. Yet, they are poorly known in the Philippines. This paper aimed to provide information on the diversity and distribution of Araneae in three habitat types: roadside, nearby stream, and mixed dipterocarp area within the ecological site using time constraint and transect walk sampling. Data revealed 5 families namely Araneidae, Clubionidae, Sparassidae, Salticidae and Tetragnathidae. The habitat nearby stream had the most number of species (22). Most of them are Araneidae (12), Clubionidae (1), Salticidae (6), Sparassidae (1) and Tetragnathidae (2). While the roadside area had only Araneidae (7) and Tetragnathidae (7) and in the mixed dipterocarp had three families: Tetragnathidae (2), Sparassidae (1) and Araneidae (3). Species richness based on Shannon Weiner Diversity Index, showed highest at the nearby stream $\left(\mathrm{H}^{\prime}=1.085\right)$, followed by the roadside $\left(\mathrm{H}^{\prime}=1.048\right)$ and lowest at the dipterocarp forest $\left(\mathrm{H}^{\prime}=0.436\right)$. The distribution of Araneae species at CEDAR Impasugong, Bukidnon is uneven. The nearby stream had dominated by Araneidae because members are associated shrub and herbs plants along the stream with their webs hang on the flyways of most insects. The roadside and dipterocarp were dominated with tall mahogany (Swietenia mahogani) and lauan (Shorea contorta) were the habitat for the Sparassidae and Araneidae. Results suggest that Araneae favors the stream as their microhabitat in CEDAR, Bukidnon.
\end{abstract}

Keywords: Spiders, Araneae, Diversity

\section{Introduction}

Spiders in order Araneae are the most diverse of all arachnids. Currently there are 114 families, 3,905 genera and 44,032 species [1]. They vary in shapes, size, predatory hunting style, web structures, eye pattern and habitat preferences. They are widely distributed from the temperate to the tropical region, except in Antartica [2]. They could be found in different types of terrestrial biomes and abundant in both urban areas, forest and agro-ecosystems. In the Philippines, [3] had identified 517 species belonging to 225 genera and 38 families and this will continue to increase. In Mindanao, there were few explorations were conducted such as the study by [4] who studied the species richness of spiders in Mt. Matutum, South Cotabato. Another study conducted [5] that identified 51 species of spiders in Mt.
Malindang Range Natural Park and a study on species richness of spiders in different elevation gradient in Brgy. Baganihan, Marilog District, Davao City [6]. There were several studies investigated the importance of spiders as ecological indicators. According to [7] and [8] who discussed the importance in studying the spiders as a reliable biological indicators. To detect the changes within the habitat caused by human interventions. Spiders may serve as biological agent to control crop insect pest and could consume approximately $200 \mathrm{~kg} \mathrm{ha}^{-1} \mathrm{y}^{-1}$ [8], [9], [10]. Their distribution, abundance and diversity would depend within the habitat. Some families may display habitat preferences and some communities fluctuate in density due to abiotic factors like temperature and humidity [9], [10]. Habitat structure and plant composition would affect spider diversity and density because the more complex the habitat it offers several microclimates for the arachnids [4]. The present study aims 
to provide a baseline checklist of spiders, to determine their diversity and their distribution within the three habitat types. This study will contribute to our growing knowledge on the distribution and ecology of spider communities in our country and served to provide a foundation for future studies.

\section{Methods and Materials}

\subsection{Sampling Site Description}

The Center for Ecological Development and Recreation (CEDAR) was located at Barangay Impalutao, Impasug-ong, Bukidnon with a total land area of about 1,703 hectares. It is located at $7.87 .67^{\circ} \mathrm{N}, 125.06 .83^{\circ} \mathrm{E}$ lies at $700 \mathrm{~m}$ asl (Figure 1). The 373 hectares was covered with man-made and natural forest. A part of CEDAR is recreation areas which open to the public. A 100-hectare rattan plantation exists in the area. Hundreds of thousands of white Lauan (Shorea contorta) trees and giant bamboos (Bambusa sp.) also contained the forest. In the study, three sites were established, site 1 the roadside going the nearby stream, site 2 nearby stream and site 3 was along the mixed dipterocarp area. Site 1 was located $752 \mathrm{~m}$ asl with a coordinates of $\mathrm{N} 08^{0} 15^{\prime} 8.00^{\prime \prime}$ and $\mathrm{E}$ $125^{\circ} 1.0^{\prime} 59.0^{\prime \prime}$. The area was quite open and along the side it consists of plants like palm species, some grasses, giant bamboo species, old growth trees and shrub. While site 2, was located $725 \mathrm{~m}$ asl with coordinates of $\mathrm{N} 08^{0} 15^{\prime} 8.00^{\prime \prime}$ and E $125^{\circ} 2.0^{\prime} 5.0^{\prime \prime}$, near along the nearby stream which consisted of herbaceous plants, some ferns like Asplenium nidus, shrubs, Arum plants, giant bamboo species, few old growth tree and grasses. Then site 3, was located $743 \mathrm{~m}$ asl with the exact coordinates of $\mathrm{N} 08^{0} 15^{\prime} 17.00^{\prime \prime}$ and $\mathrm{E} 125^{\circ} 2.0^{\prime} 11.0^{\prime \prime}$, the area found between the Calatungan Falls and Dila Falls. It was composed of giant bamboo, some fern species like Pyrrosia species and young growth trees. The forest floor was filled with leaf litters and only few grasses and shrubs thrive in. All three sites where considered a disturbed habitat.

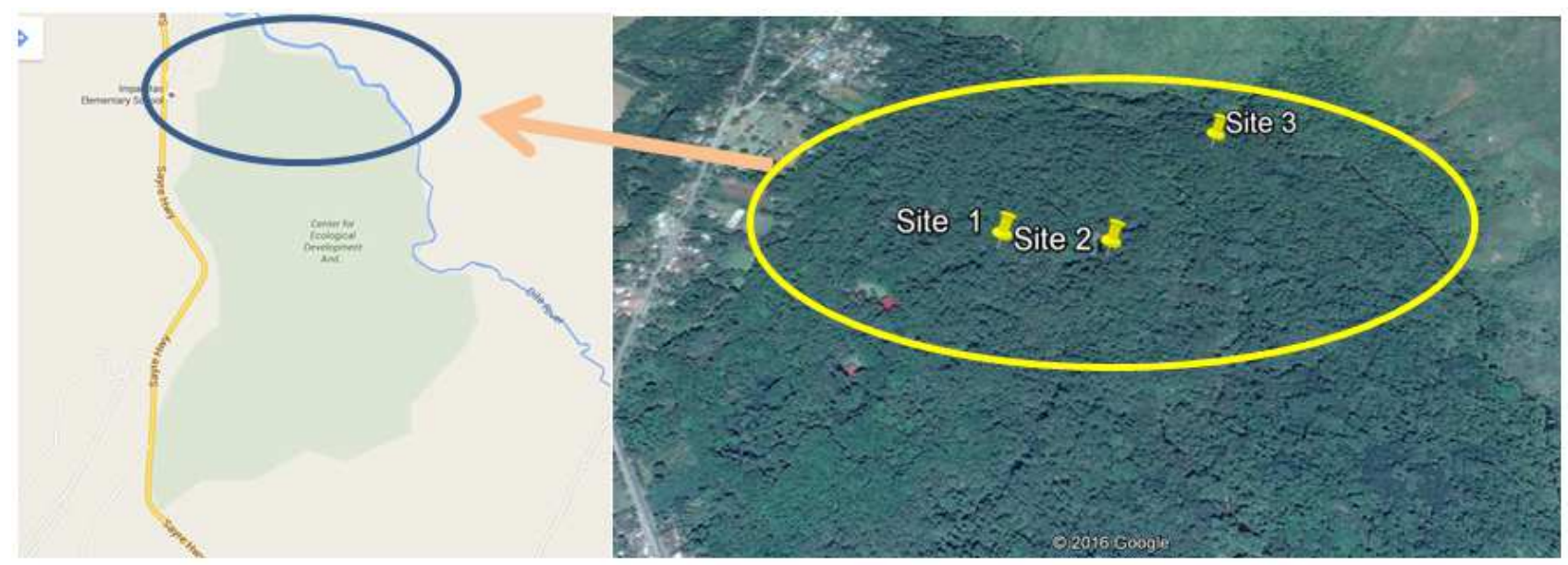

Figure 1. Site map of CEDAR, Impasug-ong, Bukidnon (left) and the sampling sites (right). (Google Earthpro).

\subsection{Sampling Methods}

Line transects were used to search the spiders within the sampling sites. Sampling was done from November 2015 to February 2016, from 1000 hours to 1500 hours in a fair weather condition. Active search, vial tapping and ground search was used to collect the samples along the path [11]. Voucher samples were documented as possible in their natural environment using a WG-5 Ricoh Digital Camera with GPS to record their actual appearance of the spiders. Then preserved with $94.5 \%$ ethyl alcohol and placed in separate containers. For identification, taxonomic keys, picture comparison from related literatures in the Philippines and other countries such as the studies of [3], [12] and field guides were used from the web [1]. Due to limited time, not all specimens were identified to a species level but as morphospecies level. Diversity was computed using Shannon Wiener Index through Bio Diversity pro. Ver.2.

\section{Results and Discussions}

Thirty species (30) belonging to 5 families under 15 genera were observed during the sampling period. These families were Araneidae, Clubionidae, Sparassidae, Salticidae and Tetragnathidae. Site 1 had only two families namely the Tetragnathidae (7) and Araneidae (7); Site 2 had 5 families namely: Araneidae (12), Clubionidae (1), Salticidae (6), Sparassidae (1), Tetragnathidae (2) and Site 3 had only 3 families, Family Araneidae (3), Sparassidae (1) and Tetragnathidae (2) as shown in Table 1. Family Araneidae was most abundant and found in all sites. [13] discussed that most of the Araneidae family where abundant within the tree-shrub layer, grassland edges or forest edges and riparian areas such as the Cyclosa species. Based on Shannon diversity index, Site $2\left(\mathrm{H}^{\prime}=1.085\right)$ was diverse when compared to Site $1\left(\mathrm{H}^{\prime}=1.048\right)$ and Site $3\left(\mathrm{H}^{\prime}=0.608\right)$ low in diversity (see Figure 2 and Table 2). The diversity of spiders where affected based on their habitat preferences that support prey groups [9]. But one study pointed out that some families of spiders like the Araneidae and Tetragnathidae required specific microclimates for web building and space for territory [13]. Site 2 was provide a greater space, then followed by Site 1 which was a mixed open and complex 
forest community and Site 3 consist of complex community webs. Open space provide fly way for insects. which provided a small space for orb weavers to build there

Table 1. Number of individuals observed in each site with their microhabitats.

\begin{tabular}{|c|c|c|c|c|c|}
\hline Family & Species & Site 1 & Site 2 & Site 3 & Microhabitat \\
\hline \multirow{15}{*}{$\begin{array}{l}\text { Araneidae (Simon, } \\
\text { 1895) }\end{array}$} & Cyclosa sp. 1 & 0 & 1 & 0 & Builds it web on the forest floor in between the shrubs. \\
\hline & Cyclosa sp. 2 & 0 & 1 & 0 & Found on the ornamental plant. \\
\hline & $\begin{array}{l}\text { Gasteracantha janiopol (Barrion } \\
\text { \& Litsinger, 1995) }\end{array}$ & 6 & 15 & 5 & $\begin{array}{l}\text { Builds it web on the forest floor using a dead twigs or small } \\
\text { shrubs for attachment. }\end{array}$ \\
\hline & $\begin{array}{l}\text { Gasteracantha parangdiadesmia } \\
\text { (Barrion \& Litsinger, 1995) }\end{array}$ & 3 & 6 & 1 & $\begin{array}{l}\text { Above the forest floor, web attached to a grass or a } \\
\text { herbaceous plant. }\end{array}$ \\
\hline & Gasteracantha sp. 1 & 1 & 0 & 0 & $\begin{array}{l}\text { Above the forest floor, web attached to a grass or a } \\
\text { herbaceous plant. }\end{array}$ \\
\hline & Gasteracantha sp. 2 & 0 & 1 & 0 & $\begin{array}{l}\text { Above the forest floor, web attached to a grass or a } \\
\text { herbaceous plant. }\end{array}$ \\
\hline & Gasteracantha sp. 3 & 0 & 1 & 0 & $\begin{array}{l}\text { Above the forest floor, web attached to a grass or a } \\
\text { herbaceous plant. }\end{array}$ \\
\hline & Gasteracantha sp. 4 & 0 & 1 & 0 & $\begin{array}{l}\text { Above the forest floor, web attached to a grass or a } \\
\text { herbaceous plant. }\end{array}$ \\
\hline & Gasteracantha sp. 5 & 1 & 0 & 0 & $\begin{array}{l}\text { Above the forest floor, web attached to a grass or a } \\
\text { herbaceous plant. }\end{array}$ \\
\hline & Agriope sp. 1 & 0 & 1 & 0 & Found the web on the Asplenium nidus plant. \\
\hline & Neoscona sp. 1 & 0 & 1 & 0 & $\begin{array}{l}\text { Found on lower understory using the dead twigs for the } \\
\text { attachment. }\end{array}$ \\
\hline & Neoscona sp. 2 & 0 & 1 & 0 & \\
\hline & $\begin{array}{l}\text { Nephila maculata } \\
\text { (Fabricus, 1973) }\end{array}$ & 6 & 5 & 3 & $\begin{array}{l}\text { The web was found from the forest floor to the understory. It } \\
\text { uses the small branch of the plant for attachment. }\end{array}$ \\
\hline & Nephila sp. 1 & 6 & 2 & 0 & $\begin{array}{l}\text { Found above the forest floor using the tall grasses or twigs } \\
\text { for attachment of its web. }\end{array}$ \\
\hline & Nephila sp. 2 & 1 & 0 & 0 & Found above the grasses. \\
\hline \multirow{7}{*}{$\begin{array}{l}\text { Clubionidae } \\
\text { (Wagner, 1887) } 023 \\
\text { Salticidae } \\
\text { (Blackwell, 1841) }\end{array}$} & Clubiona sp. 1 & 0 & 1 & 0 & Found solitary on a leaf. \\
\hline & Epeus sp. 1 & 0 & 1 & 0 & Found solitary on a leaf. \\
\hline & Chalcotropis sp. 1 & 0 & 3 & 0 & Found its nest on a leaf of Asplenium nidus. \\
\hline & Chalcotropis sp. 2 & 0 & 1 & 0 & Found solitary on a leaf. \\
\hline & Chalcotropis sp. 3 & 0 & 1 & 0 & Found solitary on a leaf. \\
\hline & Heratemita sp. 1 & 0 & 1 & 0 & Found solitary on a leaf. \\
\hline & Heratemita sp. 2 & 0 & 1 & 0 & Found on top of a herbaceous leaf together with a weevil. \\
\hline \multirow{2}{*}{$\begin{array}{l}\text { Sparassidae (Bert } \\
\text { Kau, 1872) }\end{array}$} & Heteropoda sp. 1 & 0 & 8 & 0 & Found on top of an Arum leaf. \\
\hline & Heteropoda sp. 2 & 0 & 0 & 1 & Found on the trunk camouflage with lichen. \\
\hline \multirow[t]{9}{*}{$\begin{array}{l}\text { Tetragnathidae } \\
\text { (Menge, 1866) }\end{array}$} & $\begin{array}{l}\text { Leucauge argentina } \\
\text { (Hasselt, 1882) }\end{array}$ & 5 & 15 & 5 & $\begin{array}{l}\text { Some build its web on the grass land, some on the shaded } \\
\text { areas between the buttresses of the tree. }\end{array}$ \\
\hline & $\begin{array}{l}\text { Leucauge venusta } \\
\text { (Walckaenaer, 1842) }\end{array}$ & 1 & 0 & 0 & Build its web between twigs and on the slightly open areas. \\
\hline & Leucauge sp. 1 & 1 & 0 & 0 & Build its web between twigs and on the slightly open areas. \\
\hline & Tetragnatha sp. 1 & 7 & 0 & 0 & Build its web on the basal part of the leaf of a palm plant. \\
\hline & Tetragnatha sp. 2 & 6 & 11 & 15 & Build its web on the cliff side of the road. \\
\hline & $\begin{array}{l}\text { Tetragnatha ceylonica } \\
\text { (Pickard-Cambridge, } 1869 \text { ) }\end{array}$ & 2 & 0 & 0 & $\begin{array}{l}\text { Build its web on the shaded area on the forest floor or } \\
\text { between the buttresses or tree trunks. }\end{array}$ \\
\hline & Total no. of individuals & 51 & 78 & 36 & \\
\hline & Total no. of species & 14 & 22 & 6 & \\
\hline & Total no. of Families & 2 & 5 & 3 & \\
\hline
\end{tabular}

Some families like the Family Salticidae were not found in areas with thick leaf litters like in Site 1 and Site 3 but mostly observed in Site 2 on shrubs and along the nearby stream which prevents them from desiccation [14, 15]. Salticids never use its web to capture a prey but that they are more on ambush type. Others like in Family Tetragnathidae the Leucauge sp. Usually found in lower shrubs and the buttresses of trees which support their webs [16]. The Heteropoda $s p$ (commonly known as Hunstman) is foliage runners and ambush hunter [17]. But during the second sampling in December, Site 2 the shrubs were cut down and the Huntsman were not observed. Human intervention or any anthropogenic activities could affect the spider richness and diversity because spider abundance was directly related to habitat complexity and vegetation $[9,18]$. Site 1 was likely an open space and only two families were observed, Araneidae (Genus Nephila and Gasteracantha) and Tetragnathidae (Genus Leucauge and Tetragnatha) these were the genera found within the lower canopy. Most of these groups their webs were stronger and could stand the 
wind but they were exposed to other threats like predation. Site 3 mostly the area was covered with thick leaf litters only few shrubs and composed mostly of trees and Giant bamboo.
Only few species were observed like Nephila maculata, Gasteracantha parangdiadesmia (belong to Family Araneidae), Tetragnatha $s p$ and Heteropoda $s p$.

Table 2. Comparison of shannon results among the three sites.

\begin{tabular}{llll}
\hline Index & Site 1 & Site 2 & Site 3 \\
\hline Shannon H' Log Base 10. & 1.048 & 1.085 & 0.608 \\
Shannon Hmax Log Base 10. & 1.146 & 1.342 & 0.778 \\
Shannon J' & 0.915 & 0.809 & 0.782 \\
\hline
\end{tabular}

Sthannon Index Results

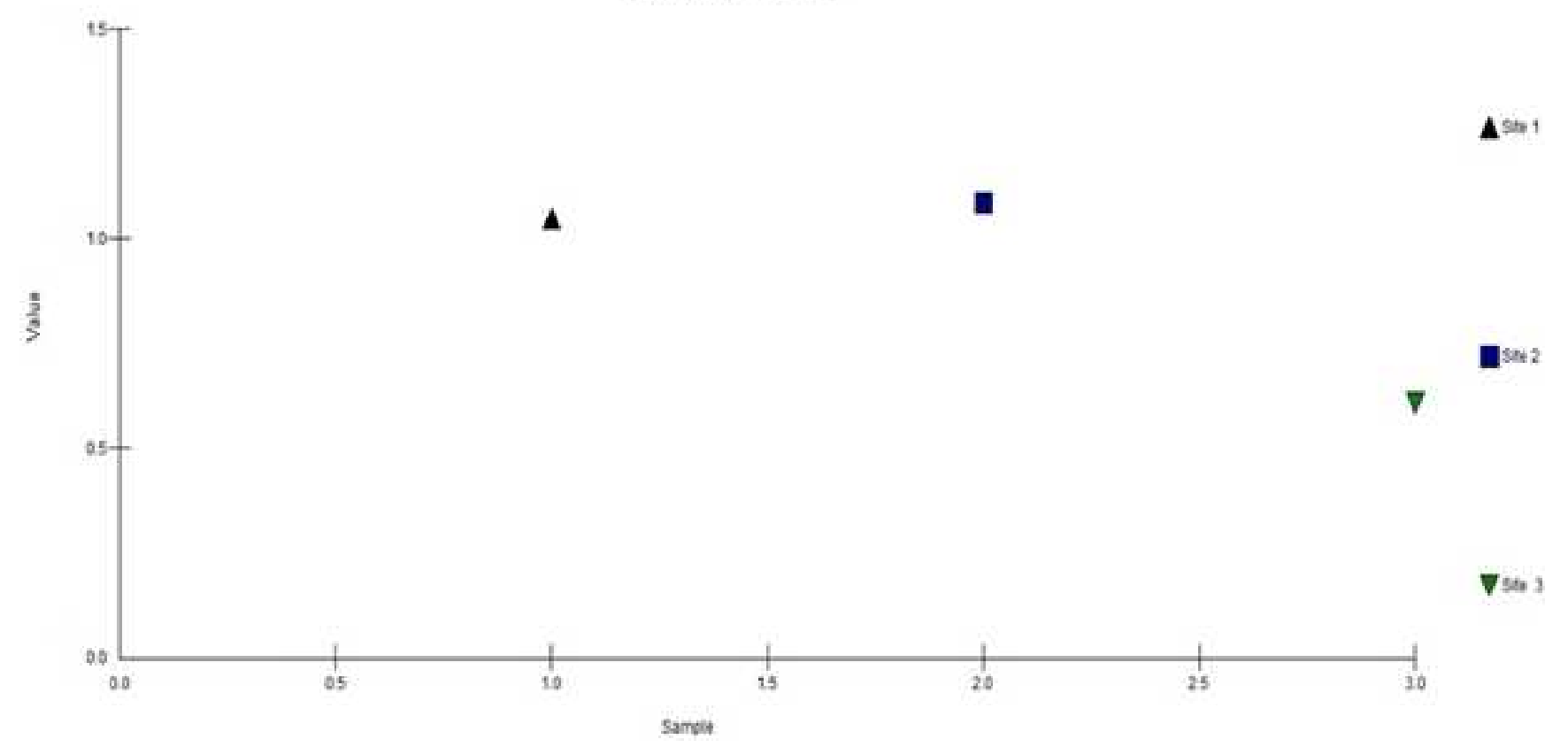

Figure 2. Diversity of three sites using Shannon Wiener Diversity Index.

Order Araneae: Family Araneidae and their distribution.

Genus: Cyclosa

The genus Cyclosa were known for their decorative design on their web as their camouflage to deceive the prey. They were distributed from temperate forest to the tropical region. [12] showed that there were 165 species worldwide and 22 species were found in the Philippines. These species preferred to build its web near the forest floor at the forest edge [10].

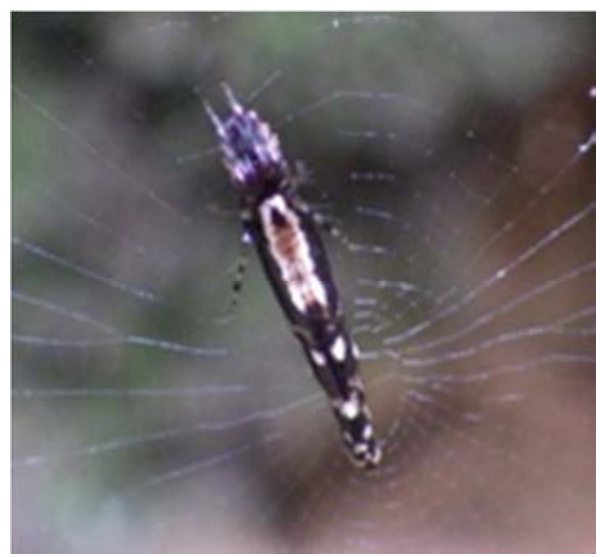

Figure 3. Cyclosa sp. 1.

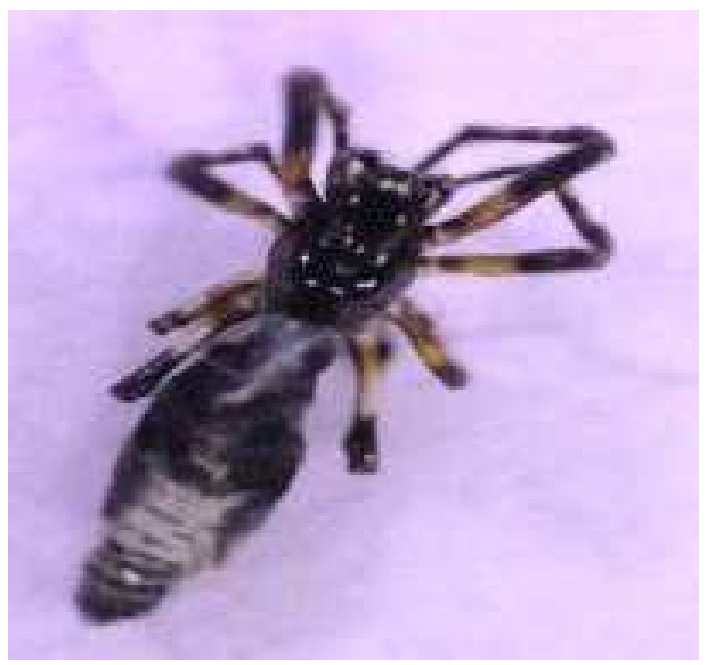

Figure 4. Cyclosa sp. 2.

Genus: Gasteracantha

As known as Spiny Orb weaver because of the spines and hard carapace. It is widely distributed from the temperate to tropical forest. There were 69 species recorded worldwide and 11 species were known in the Philippines [12]. Some species were considered as invasive species to coastal areas [19]. 


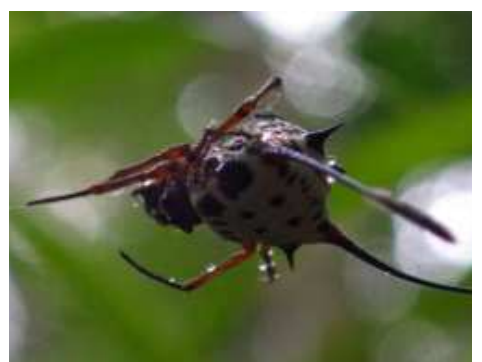

Figure 5. Gasteracantha janopol.

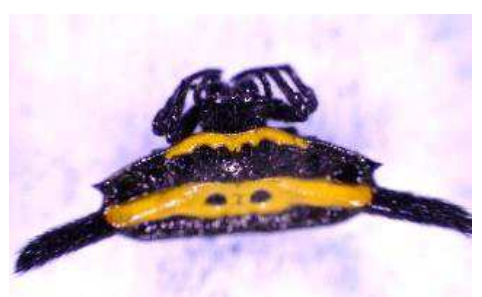

Figure 6. Gasteracantha parangdiadesmia.

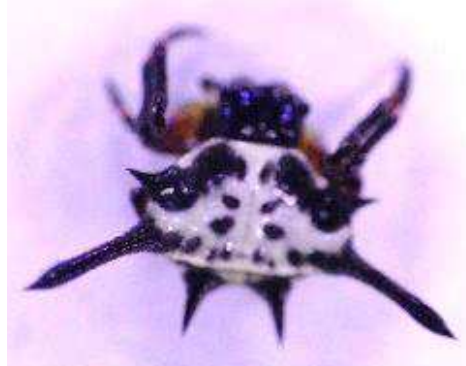

Figure 7. Gasteracantha sp.

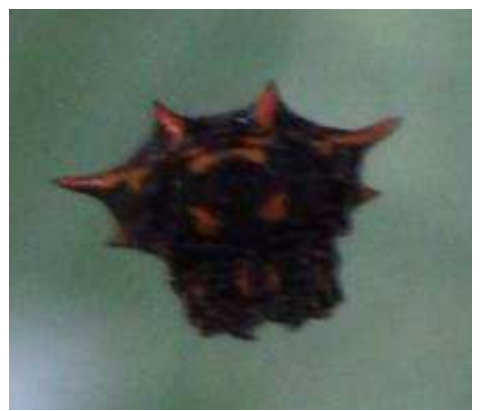

Figure 8. Gasteracantha $s p$

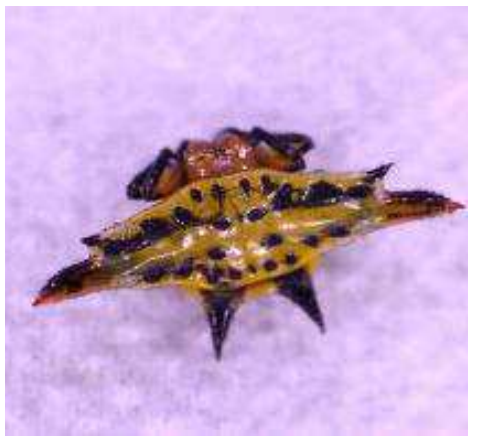

Figure 9. Gasteracantha sp.

Genus: Agriope

The genus Agriope are widely distributed from the tropics to the temperate regions. They are known for striking pattern on their abdomen and its zigzag form on their webs called the stabilimentum. In the Philippines, they are known as gagambang ekis ("X spider", again due to the stabilementa). Woldwide there are 76 species recorded and 6 were found in the Philippines [12].

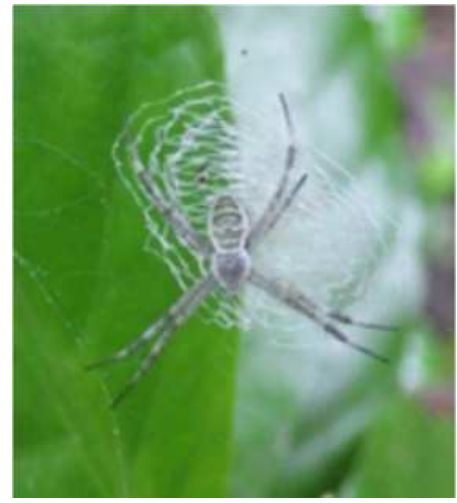

Figure 10. Agriope sp.

\section{Genus: Neoscona}

The genus Neoscona are pantropical in distribution. There abdomen had a distinguishing pattern and longitudinal groove on the carapace which separates all species which separates them other species in Araneus. Worldwide there were 81 species and 11 were recorded from Philippines [12]. This group preferred areas with high prey density [20].

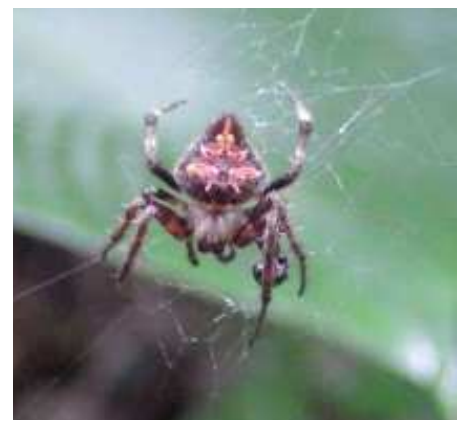

Figure 11. Neoscona sp.

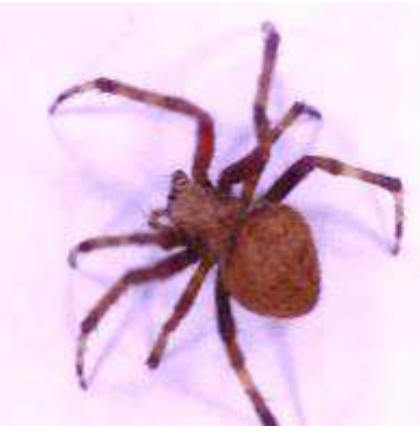

Figure 12. Neoscona sp.

Genus: Nephila

Nephila is known a oldest surviving genus of spiders and it is also known as the Golden Silk orb-weaver. Golden silk orb-weavers are widespread in warmer regions throughout 
the world, with species in Australia, Asia, Africa and America. This group of spiders preferred warmer condition of habitat. Old records that 105 species were recorded worldwide and 3 species were known in the Philippines [12].

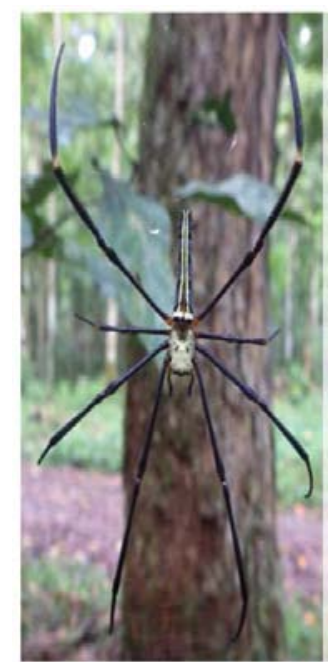

Figure 13. Nephila maculata (female).

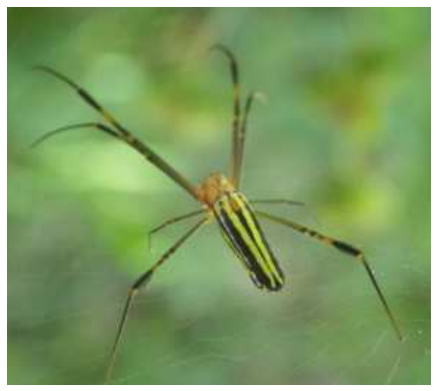

Figure 14. Nephila sp.

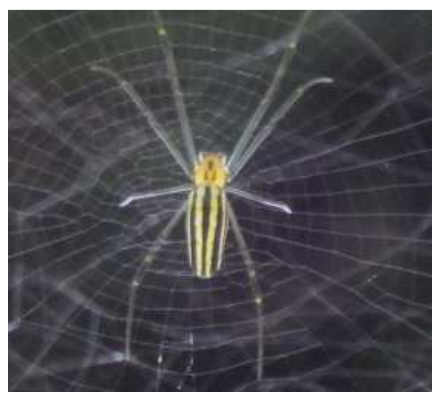

Figure 15. Nephila sp.

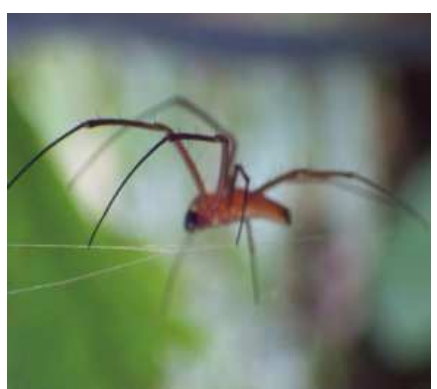

Figure 16. Nephila maculata (male).
Widely distributed from temperate to the tropical regions. At present there are 426 species recorded and 20 species were known in the Philippines [12]. This group usually found within the bushes [21].

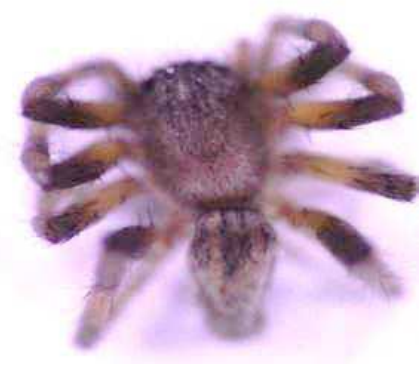

Figure 17. Clubiona sp.

Family Sparassidae: Genus Heteropoda

This main group of Sparassidae distributed in the tropical region of Asia and Australia. Worldwide there are 209 species and 2 were known in the Philippines. These are known foraging spiders, they don't built webs to capture prey but more or ambush type of strategy [12].

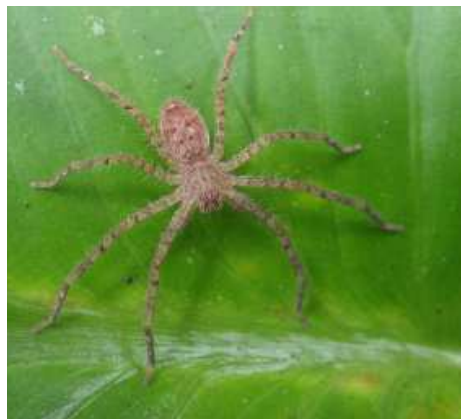

Figure 18. Heteropoda sp.

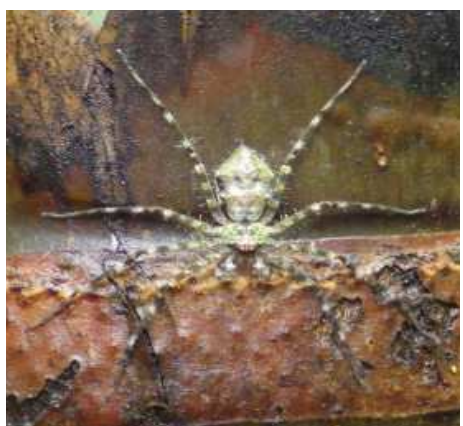

Figure 19. Heteropoda sp.

Family Salticidae

Genus: Epeus, Heratemita and Chalcotropis

Family Salticidae are known as the jumping spiders the largest family of all spiders. It consist 500 described genera and 5,000 ++ identified species worldwide. They live in variety of habitats from the temperate to tropical regions and from the lowest elevation to high elevation [12]. Mostly found shrub areas, study showed there were some species that feed on nectars $[22,23,24,25,26]$.

Family: Clubionidae: Genus Clubiona 

Impasug-Ong Protected Area, Bukidnon, Philippines

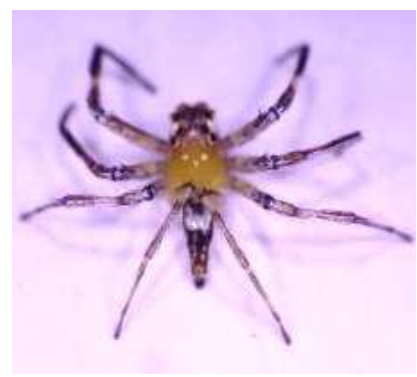

Figure 20. Epeus sp.

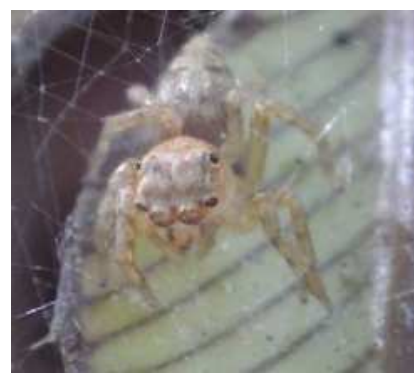

Figure 21. Chalcotropis sp.

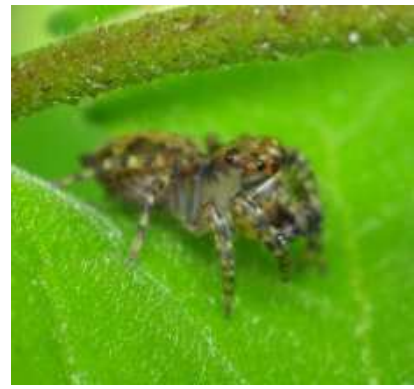

Figure 22. Chalcotropis.

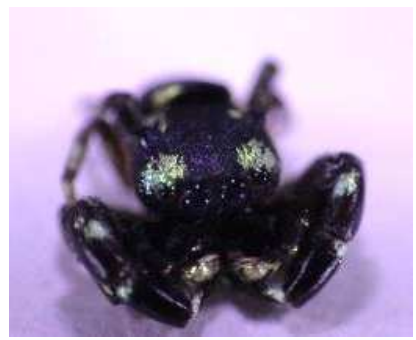

Figure 23. Heratemita sp.

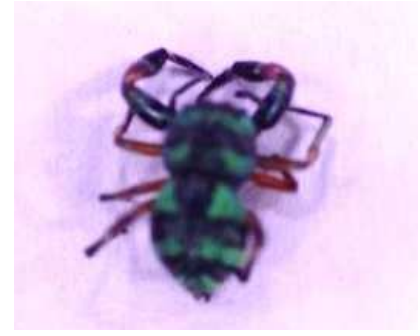

Figure 24. Heratemita sp.

Family Tetragnathidae

Genus: Leucauge (White, 1841)

There were 165 species identified worldwide. They are pantropical in distribution

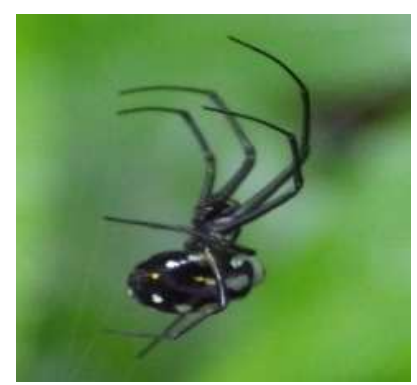

Figure 25. Leucauge argentina.

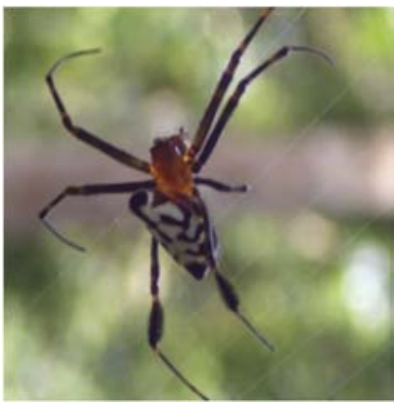

Figure 26. Leucauge venusta.

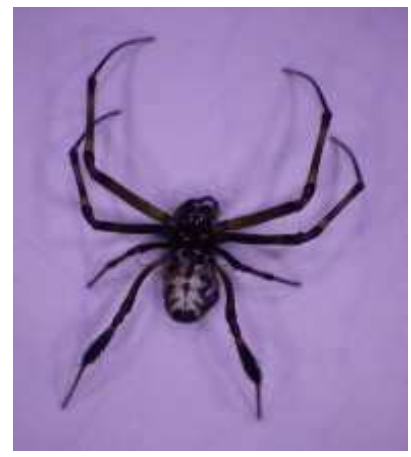

Figure 27. Leucauge argentina.

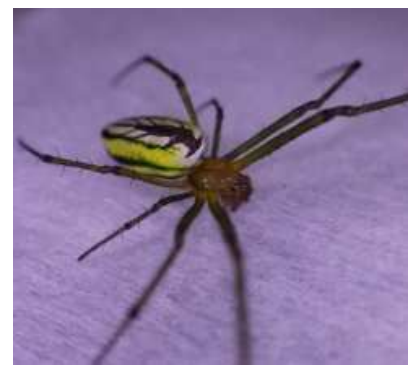

Figure 28. Leucauge sp.

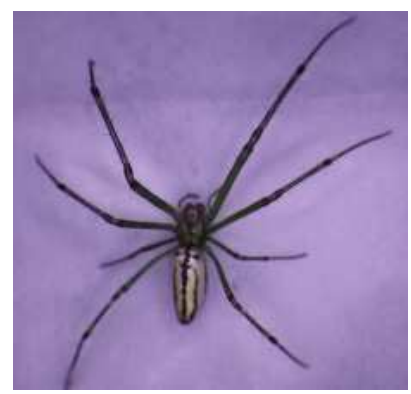

Figure 29. Leucauge sp. 


\section{Conclusion}

This study served as a baseline for the future research on spiders within the protected area. Since it was only conducted in limited time there were areas that unexplored. To further note other unrecorded species or families, it was recommended to use several methods of collection like pitfall traps and sweep netting in order to capture ground dwelling spiders and for spiders located in middle canopies. Such spiders like in Family Sparassidae or the Hunstman spiders usually observed solitary who don't weave webs for hunting but more on ambush or lie and wait strategy. Even though the area was protected by the government, still it was considered as one tourist destination in the province. In which areaneofauna were exposed to several anthropogenic activities that could alter microhabitats and affect their population. One good example in the family of Sparassidae, where during the first month of sampling, this group usually seen on top of the Arum plant waiting for its prey. But on the following month, a portion of the stream bed was altered by the forest $\mathrm{s}$ guards by removing the Arum plants along the path of the nearby stream to give way for the tourist security. During that month no collection or sightings of that group, but only dead remains of huntsman were observed. Every family had certain preferences in terms of their microhabitats to occupy but this would depend of certain factors: abiotic factors, shading, presence of vegetation, complexity of the habitat, food availability and space. The abundance of flora and fauna is the key to build microhabitats. Anthropogenic disturbances greatly affect the distribution, diversity and primary threat to spiders.

\section{References}

[1] World Spider Catalog. (2016). World Spider Catalog. Natural Museum, online at http://wsc.nmbe.ch.version17.0.accessed on January 31, 2016.

[2] Sewlal, J. A. N., \& Cutler, B. (2003). Annotated list of spider families (Araneida) of Trinidad and Tobago.

[3] Barrion AT. (2001). Spiders: natural biological control agents against pest in Philippine rice fields. Transactions of the national Academy of Science and Technology, Philippines 23, 121-130.

[4] Enriquez CMD and Nuñeza, OM. (2014). Cave spiders in Mindanao, Philippines. Extreme Life, Biospeology, \& Astrobiology- International Journal of the Bioflux Society 6(1), 46-55.

[5] Ballentes MG, MOhagan AB, Gapud VP, Espallardo MCP, Zarcilla MO. (2006). Arthropod Faunal Diversity and Relevant Interrelationships of Critical Resources in Mt. Malindang, Misamis Occidental Southeast Asian Regional Center for Graduate Study and Research in Agriculture (SEARCA), p. 1-166.

[6] Chua JC, Uba MO, Carvajal TM. 2014. A Rapid Assessment of spider diversity in Kabigan Falls, Pagudpud, Ilocos Norte, Philippines. Journal of Systematic Biology 8, 16-26.
[7] Kremen C, Colwell RK, Erwin TI, Murphy DD, Noss RF, Sanjayan MA. (1993). Terrestrial arthropod assemblages their use in conservation planning. Conservation Biology 7, 796-808.

[8] Lee, J. H. \& Kim, S. T. (2001). Use of spiders as natural enemies to control rice pest in Korea. Food and Fertilizer Technology Center.

[9] Maefait JP, Hendrickx F. (1998). Spiders as biological indicators of anthropogenic stress in natural and semi-natural habitats in Flanders (Belgium): Some recent developments. In: Selden PA, Ed. Proceedings of the $17^{\text {th }}$ European Colloquim of Arachnology. Edinburgh. 293-300.

[10] Miyashita, T. (1997), Factors affecting the difference in foraging success in three co-existing Cyclosa Spiders. Journal of Zoology, 242: 137-149. doi: 10.1111/j.14697998.1997.tb02935.x.

[11] Chetia, P., \& Kalita, D. K. (2012). Diversity and distribution of spiders from Gibbon Wildlife Sanctuary, Assam, India.

[12] Platnick, Norman I. (2014). The world spider catalog, version 14.5. American Museum of Natural History. doi: 10.5531/db.iz.0001

[13] Rodrigues, E. N., Mendonça Jr, M. D. S., Rodrigues, P. E., \& Ott, R. (2015). Diversity, composition and phenology of araneid orb-weavers (Araneae, Araneidae) associated with riparian forests in southern Brazil. Iheringia. Série Zoologia, 105(1), 53-61.

[14] Romero, G. Q., \& Vasconcellos-Neto, J. (2005). Spatial distribution and microhabitat preference of Psecas chapoda (Peckham \& Peckham) (Araneae, Salticidae). Journal of Arachnology, 33(1), 124-134.

[15] Romero, G. Q. (2006). Geographic Range, Habitats, and Host Plants of Bromeliad - living Jumping Spiders (Salticidae) 1. Biotropica, 38(4), 522-530.

[16] Gillespie, R. G., \& Reimer, N. (1993). The effect of alien predatory ants (Hymenoptera: Formicidae) on Hawaiian endemic spiders (Araneae: Tetragnathidae). Pacific Science, 47(1), 21-33.

[17] Juario JV, Nuneza OM, Dupo, AL. (2016). Species richness in spiders in Sacred Mountain, Marawi Cit. Journal of Biodiversity and Environmental Sciences. Vop18 no. 1 p 86-94

[18] Pinkus Rendón, M. A., Ibarra-Nú; atnez, G., Parra-Tabla, V., García-Ballinas, J. A., \& Hénaut, Y. (2006). Spider diversity in coffee plantations with different management in Southeast Mexico. Journal of Arachnology, 34(1), 104-112.

[19] Truong, H. (2012). Coloration in relation to ecology in the Asian spiny-backed spider, Thelacantha brevispina (Araneae, Araneidae) on Moorea, French Polynesia.

[20] Adams, M. R. (2000). Choosing hunting sites: web site preferences of the orb weaver spider, Neoscona crucifera, relative to light cues. Journal of insect behavior, 13(3), 299-305.

[21] Pollard, S. D., \& Jackson, R. R. (1982). The biology of Clubiona cambridgei (Aranea, Clubionidae): intraspecific interactions. New Zealand journal of ecology, 44-50.

[22] Robert R. Jackson, Simon D. Pollard, Ximena J. Nelson, G. B. Edwards and Alberto T. Barrion (2001). Jumping spiders (Araneae: Salticidae) that feed on nectar. Journal of Zoology, 255, pp 25-29. doi: 10.1017/S095283690100108X. 
[23] Buchholz, S. (2009). Community structure of spiders in coastal habitats of a Mediterranean delta region (Nestos Delta, NE, Greece). Animal Biodiversity and Conservation, 32(2), 101-115.

[24] Nyffeler, M. (2000). Ecological impact of spiders predation: a critical assessment of Britowe's amd Turnbull's estimates. Bulletin on the British Arachnological Society, 11(9), 367373 .
[25] Peckmezian, T. (2009). A baseline study of the spider at a Costa Rican cloud forest reserve. Cloudbridge Nature Reserve, Costa Rica.

[26] Ward, L. (2007). Habitat Specificity of Selected Spiders of Dominica. Texas A\&M University, Study Abroad Dominica Program, 1-16. 